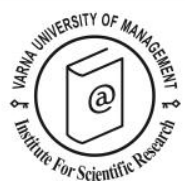

\title{
Raj, Razaq \& Griffin, Kevin (Eds) (2017). Conflicts, Religion and Culture in Tourism. Wallingford \& Boston: CABI
}

\author{
Reviewed by Trevor Sofield ${ }^{1}$
}

Received: 01/07/2018

\footnotetext{
${ }^{1}$ Visiting Professor, Sun Yat Sen University, China. E-mail: trevor.sofield@utas.edu.au

(C) 2018 Varna University of Management. All rights reserved
}

Citation: Raj, Razaq \& Griffin, Kevin (Eds) (2018). Conflicts, Religion and Culture in Tourism. Wallingford \& Boston: CABI. Reviewed by Trevor Sofield, European Journal of Tourism Research 20, pp. 159-163

It is impossible to do justice to the diversity of topics, issues and challenges that are presented in the 176 pages of this book in a short review. While I have my own views about the sometimes varied quality of the 14 chapters, each and every chapter merits its own detailed scrutiny, and this task is aided by the points for discussion (4 for each chapter) listed in the final chapter (15) identified by the authors of each chapter. Numerous other questions raise their heads as you read this volume and for any course investigating religions, conflicts, culture and tourism, it is well worth the investment.

The co-editors have arranged the chapters logically in three sections, prefaced by their thoughtful and wide-ranging introductory overview: (I) Conflict, religion, culture and tourism; (II) (Re)Claiming space - modern reinstatements of religion and pilgrimage; and (III) Understanding 'Others': Conflicts, challenges and issues. Before delving into each section, however, I wish to make a general observation. Commentary on religion and religious beliefs, combined with culture, is sensitive at any time, and to juxtapose these BOOK REVIEW topics with conflict is brave. In anthropology, sociology and philosophy (among other disciplines) it is standard practice in dealing with these and other questions, including ethical issues, etic (outsider) analysis and interpretation of another society's structures and values, to accept that we are all subjective no matter how hard we strive for objectivity and thus researchers state the specific standpoint(s) from which they enter a particular field of enquiry (Iphofen 2013). Is one male/female, Caucasian/Asian, black/ white, atheist/agnostic/religious (with religion identified), young/old, a native speaker/no local language skill, are there vested interests, etc? Such a statement has a twofold purpose: (a) it helps to make the researcher aware of the potential for bias by acknowledging such aspects, and to take steps to neutralize personal attributes that could affect the outcome of research endeavours; and (b) it may also help the reader to better understand and assess the validity of what may be written.

In opening this book I searched in vain for such declarations at the beginnings of each 
Raj, Razaq \& Griffin, Kevin (Eds) (2018). Conflicts, Religion and Culture in Tourism. Wallingford \& Boston: CABI. Reviewed by Trevor Sofield, European Journal of Tourism Research 20, pp. 159-163

chapter, and only one - Ch.2, 'Consciousness in Conflict' by Suleman and Qayum specifically states at the end of its introduction that the authors are addressing the topic "through an Islamized lens" (p.13). Their outline of 'darklight tourism', 'indoctritaiment' 'orthopraxy' and 'mythopolitics' as paths to understand tourism as a world view, and as expressions of identity and mobility, are in fact more universal than Islamist and merit careful reading. To try and ascertain the particular standpoint of other authors, the notes on Contributors offers some guidance, but for about half of them there is no definitive statement.

\section{Section I: Conflict, religion, culture and tourism}

Chapter 3 (by Chowdhury and Razaq Raj), which follows on from Suleman and Qayum, explores the vexed issue of freedom of speech on the one hand and respect for religious beliefs and protection against blasphemy on the other, in the context of the UN Declaration on Human Rights which purports to be universal. While examples from different countries/societies are drawn upon, this chapter tends to be slanted towards an Islamic perspective using the 2005 Danish cartoons incident that sparked worldwide outrage by Muslims who perceived them to be blasphemous, and the 2015 Charlie Hebdo (Parisian satirical magazine) killings for which Al Quaeda claimed responsibility to illustrate its points (although there is no clear statement about the standpoints and religious backgrounds of the two authors). Perhaps a more balanced exploration of the inherent conflict between these two opposing human right values could have been attained by drawing upon the response of other religions to perceptions of blasphemy where in secular (mainly western) societies freedom of speech tends to be granted priority over expression of religious beliefs. Nevertheless, this is a chapter that provokes profound thought and it is difficult to deny their final suggestion that international and national definitions of human rights need to strive collectively and individually for a better equilibrium between the two fundamental rights if conflict over religious beliefs is to be minimized.

160
Whether religious tourism is a precondition for conflict is the question posed by the three authors (two from Argentina, one from Cuba) of Chapter 4. This paper strives hard to link hospitality towards 'outsiders' as envisioned by many religions, venturing into a global perspective to argue that religion and tourism are inherently connected. While not always convincing in my view, it raises issues worthy of serious discussion.

Ifan Raja, University of Huddersfield, UK, one of the co-authors (with Razaq Raj) of Chapter 5, 'The Essence of Community Cohesion through Religious Tolerance' is described, intriguingly, in the Contributors' notes as "a campaigner" who is active "in reporting terrorism, community cohesion, media representation of Islam and Muslims, and Islamaphobia" (p.ix), but from what perspective we do not know. I found this chapter one of the less satisfying since it emphasizes mainly those Quranic verses which stress harmony and peace and glosses over some of the 'hard questions', for example avoiding specific quotes from the Quran which specify waging war on unbelievers used by IS and other Islamic terrorist organizations to justify their violence (e.g. Sura 2:89, Sura 5.51, The Quran, Dawood 2006). Contradictions within the Quran are bypassed. The opportunity to discuss how to weight these contradictions differentially, and why those emphasizing harmony and peace should (must) be given overwhelming preference, has been lost. For a strong, Islamic legally-oriented exposition of some of the 'hard' issues that Islam could confront, see the address by the Malaysian activist, Zainah Anwar, a founding member and former executive director of Malaysia's 'Sisters in Islam', currently the director for 'Musawah', a global movement for equality and justice in the Muslim family, that she delivered at the 'Women of the World Festival' in Brisbane, 6 April 2018. She makes a distinction between Syari'ah law and fiqh, (literally "understandings") and lays down a potent challenge to fellow Muslims to question some fiqh, the process by which Imams, some Islamic governments and terrorist organizations interpret and attempt to derive 
Raj, Razaq \& Griffin, Kevin (Eds) (2018). Conflicts, Religion and Culture in Tourism. Wallingford \& Boston: CABI. Reviewed by Trevor Sofield, European Journal of Tourism Research 20, pp. 159-163

legal rules and justification for activities and behavior from the Quran and the Sunnah (practices) of the Prophet: she states that certitude belongs only to God, so while Syari'ah, God's revelation, is immutable and infallible, figh is changeable and fallible, a human construction.

\section{Section II: (Re)Claiming Space}

Pierre Wiktorin (chapter 6, the first chapter in this section) is identified in the notes on contributors as a lecturer in religious studies at the Mid-Sweden University but from which religious affiliation (if any) we do not know. His paper on the re-Christianization of Sweden, together with its companion chapters on the 'artificial' creation of new pilgrims' trails in the Czech Republic (by Jan Raja), and on the 'hidden Christians' of Japan and their 400 year old heritage (by Tinka Kawashima), are fascinating examples of how tourism organizations rather than religious organizations themselves are the drivers in creating new forms of pilgrimage tourism in these countries; the historical authenticity of the new pilgrim trails is mainly absent as tourism marketeers strive to increase visitation and resort to artificial devices by capturing religion as just one arrow in their quiver to achieve that objective. The fourth chapter in this section examines the tension between the Marxist-inspired hostility towards religions implemented by the communist government of Cuba and the resilience of people-located Catholicism over the past 50 years, with an emerging potential for religious tourism. While the notes on contributors lead to the assumption that most of these authors are natives of the four countries concerned we have no idea of their religious affiliations or non-affiliations.

\section{Section III: Understanding Others: Conflicts Challenges and Issues}

The opening chapter in this section - 'Visiting Graves, Tombs and Shrines in Islamic Law' by Necmeddin Guney - sits a little awkwardly with the title of the book since its relationship with conflict and tourism is minimal, although it is obviously substantial on religion and culture. The biographical notes identify Guney as a professor of Islamic law in the
Faculty of Theology, Necmettin Erbakan University in Konya, Turkey, and he provides an emic understanding of this topic that only a specialist in Islamic law could elucidate. For those interested in halal tourism it provides an authoritative entrée into this topic.

For chapter 11 all four authors (Singh, Srivastara, Sonker and Rajan) are associated with the School of Architecture in Bhopal, India, and given their names and the topic of their research - the reclaiming of an ancient Muslim site at Ayodhya as an exclusive Hindu-only site for the god Ram - it may be assumed that they are not only Indian but possibly Hindu (although not necessarily so) and a declaration of their standpoint(s) would allow the reader to critique their observations and conclusions a little more deeply. Having said that, their detailed analysis of sociospatial connectivity to the physical and metaphysical worlds (drawing in part on Lefebvre's (2011) concept of 'Rythmanalysis' on space and time) lays the foundation for an interesting discussion on the events which have unfolded over almost 450 years when Ayodhya was first established by the Mughul Muslim rulers of Delhi as a major site of worship leading up to the conflict and violence from the 1950s until 1992 when Hindu extremists destroyed the last vestiges of Muslim mosques and associated architecture. This conflict between the Muslim and Hindu heritage of Ayodhya has been described as the 'Battle for the Soul of India' (Pokharel and Beckett 2012), and this chapter is notable as the only one that incorporates some (limited) commentary on Hinduism.

Bilim and Ozur, the authors of Chapter 12, 'Halal Tourism: The case of Turkey', while not identified as Muslim could be assumed to be such in order to write so authoritatively on the topic. Their comprehensive list of ensuring tourism adheres to halal requirements (Table $12.1 \mathrm{~m} \mathrm{p}, 133$, which covers accommodation and hotel services, transportation services, health care facilities and spas, and other services such as shopping centres, conference venues, sports events, etc) is a 'must-read' inventory for anybody wanting to 
Raj, Razaq \& Griffin, Kevin (Eds) (2018). Conflicts, Religion and Culture in Tourism. Wallingford \& Boston: CABI. Reviewed by Trevor Sofield, European Journal of Tourism Research 20, pp. 159-163

understand halal tourism operations, services and facilities.

The culture of orthodox Judaism as it relates to the need to provide kosher food as an essential component of the hospitality and accommodation services for Jewish tourists is aired in the lengths to which a hotel in Greece went to meet the needs of a group of 500 French Jews. This included banning the hotel staff from the kitchen three days before the arrival of the group to allow a team of certified Jewish kosher experts to 'purify and sanctify' the area through preforming special rituals and purchase and prepare the food under the supervision of a rabbi. The three authors of this chapter, Moira, Mylonopolous and Vasilopoulou are all of Greek origin, but their religious affiliation was not stated. They make the valid point that for many tourists religion determines their choice of food and that in many instances the hospitality industry is poorly equipped to deal with special needs.

The final chapter in this section is also authored by Mylonopolous, Moira and anther Greek academic, Katerina Kikilia, and they explore the lack of meaningful international treaties including UNESCO's various protocols and conventions to safeguard built heritage in times of war. They use graphic examples of the destruction of built heritage justified on religious as well as ethnic grounds as occurred when the former Yugoslavia broke up into seven new states, the Turkish invasion of Cyprus in 1974 which cut the country in half and resulted in the destruction of more than 500 churches and monasteries, and the (ongoing) war in Syria where various combatants have all been implicated in massive destruction of archaeological sites, including the destruction of most of the world heritage listed ancient city of Palmyra by the IS terrorist organization in 2015. The not unexpected conclusion drawn by the authors is that while the international community has put a legal framework in place to protect the built cultural environment and the fabric of significant religious sites, the reality of armed conflict makes it impossible to achieve.

\section{Overall comment}

While there is much of interest in this book, I remained disappointed at its selective coverage. Islam and Christianity are well represented (I would suggest 6 and 4 chapters), Hinduism features in one chapter, and Jewish kosher food in an another - but I looked in vain for contributions examining conflict, culture and tourism related to other world religions such as Buddhism, Daoism, Shintoism, Sikhism, and animistic belief systems. All religions claim to be vehicles for harmony and champions of peace, but their practice in many parts of the world reveals that their ideals are subordinated to violent proselytization by extremists. One has only to look at the allegations of Buddhist genocide against Rohingya Muslims in Myanmar and Buddhist-Tamil violence in Sri Lanka, (Arnold \& Turner 2018), of Government-backed rampages of Christians against nonChristians in Southern Sudan, of Hindu extremism perpetrated against Muslims and Christians in India, of Jewish/Muslim violence in the Middle East, as just a few examples among many, to see that this book at times fails to confront the reality of religious-inspired conflict in many parts of the world. In other instances it is same religion against same, vide the Buddhists of Thailand and Cambodia as they confront each other over the UNESCO world heritage-listed Preah Vihear temple in Cambodia: since 2010 each country has stationed a platoon (900 soldiers) armed with heavy artillery facing off against each other just 200 metres apart, engaging in occasional armed conflict (Sofield, 2006); or Shiite Muslims against Sunni Muslims in several countries; or the Protestant/Catholic hostilities that bedeviled peace in Northern Ireland until recently; or the various Buddhist sects in Tibet which had been engaged in sporadic internecine warfare for several centuries up to the time of and under the Dalai Lama before the Chinese assumed full control in 1959. All of these have their impacts in various ways and to varying degrees on tourism and pilgrimage and the fissiparous tendencies that they evidence merit the spotlight of further research being directed towards them. In short, there is ample scope for a second volume exploring 
Raj, Razaq \& Griffin, Kevin (Eds) (2018). Conflicts, Religion and Culture in Tourism. Wallingford \& Boston: CABI. Reviewed by Trevor Sofield, European Journal of Tourism Research 20, pp. 159-163

the same themes but broadening the reach to include other religions, regions and societies. In any such volume I strongly recommend that all authors provide a brief statement outlining the specific standpoint from which their research has been launched.

[In the spirit of divulging my own standpoints, ethnically my parents were migrants (English/Italian origin), I was born in Australia of protestant Christian background; a social anthropologist (first degree) spending a year working with traditionally oriented Australian Aborigines; then an Australian diplomat for 20 years serving inter alia for 3 years in Tanzania (Muslim majority with numerous Christian others), 2 years in Buddhist Sri Lanka with its large Hindu minority and smaller Muslim populations), 2 years working on United Nations' social and technical agencies, 1 year in Singapore (mixed Christian, Hindu, Daoist, Buddhist, Muslim society), 4 years in Solomon Islands, and then 2 years in Fiji (a balance of Christian and Hindu faiths) etc. For the past 25 years I have been an academic and consultant with inter alia teaching and researching as a Visiting Professor in China and Hong Kong for 20 years; 2 years as a UNDP consultant in Nepal, then a Hindu Kingdom with a very strong Buddhist heritage and a Muslim minority, (which included planning the development for pilgrimage of Buddha's birthplace, Lumbini, and integrating the surrounding marginalized Muslim minority communities into its development); 3 years in Buddhist Cambodia as Team Leader for the Mekong Tourism Development Project; 3 years teaching and research with the Universiti Teknologi Malaysia (Muslim majority); and research and consultancy projects in another 30 Asian, Pacific, African and South American countries covering all of the major religions of the world.]

\section{References}

Anwar, Zainah (2018). To Build a More Just Malaysia, We Need a More Complex Understanding of Islamic Legal Theory. Address at the 'Women of the World Festival', Brisbane, QId, Australia, 6 April 2018.

Arnold, Dan \& Turner, Alicia (2018). Why are we surprised when Buddhists are violent? Paper commissioned by the Stevanovich Institute, University of Chicago. Published in New York Times, 5 March 2018.

Iphofen, Ron (2013), Research Ethics in Ethnography/Anthropology. Brussels: European Commission

Lefebvre, H. (2011) Rythmanalysis: Space, Time and Everyday Life. Minneapolis: University of Minnesota Press.

Pokharel, K. \& Beckett, P. (2012). "Ayodhya, the Battle for India's Soul." The Wall Street Journal, 3 December 2012.

Sofield. T.H.B. (2006) Border tourism and border communities: An overview. Tourism Geographies, vol.8, no.2, pp.101-121.

The Koran. Translated by N J Dawood. 10th Edition, 2006. London: Penguin Books 